\title{
Host-pathogen-environment interactions determine survival outcomes of adult sockeye salmon (Oncorhynchus nerka) released from fisheries
}

\author{
Amy Teffer ${ }^{1}$, Scott Hinch ${ }^{2}$, Kristina Miller ${ }^{3}$, David Patterson ${ }^{3}$, Arthur Bass ${ }^{4}$, Steven \\ Cooke $^{5}$, Anthony Farrell ${ }^{6}$, Terry Beacham ${ }^{7}$, Jacqueline Chapman ${ }^{8}$, and Francis Juanes ${ }^{1}$ \\ ${ }^{1}$ University of Victoria Department of Biology \\ ${ }^{2}$ The University of British Columbia Faculty of Forestry \\ ${ }^{3}$ Fisheries and Oceans Canada \\ ${ }^{4}$ Affiliation not available \\ ${ }^{5}$ Carleton University \\ ${ }^{6}$ The University of British Columbia Department of Zoology \\ ${ }^{7}$ Pacific Biological Station \\ ${ }^{8}$ Carleton University Department of Biology
}

May 13, 2021

\begin{abstract}
Incorporating host-pathogen(s)-environment axes into management and conservation planning is critical to preserving species in a warming climate. However, the role pathogens play in host stress resilience remains largely unexplored in wild animal populations. We experimentally characterized how independent and cumulative stressors (fisheries handling, high water temperature) and natural infections affected the health and longevity of released wild adult sockeye salmon (Oncorhynchus nerka) in British Columbia, Canada. Returning adults were collected before and after entering the Fraser River, yielding marineand river-collected groups, respectively. Fish were exposed to a mild (seine) or severe (gill net) fishery treatment at collection, and then held in circulating freshwater tanks for up to four weeks at historical $\left(14^{\circ} \mathrm{C}\right)$ or projected migration temperatures $\left(18^{\circ} \mathrm{C}\right)$. Using weekly nonlethal gill biopsies and high-throughput qPCR, we quantified loads of up to 46 pathogens with host stress and immune gene expression. Marine-captured fish had less severe infections than river-captured fish, a short migration distance $(100 \mathrm{~km}, 5-7 \mathrm{~d})$ that produced profound infection differences. At $14^{\circ} \mathrm{C}$, river-collected fish survived 1-2 weeks less than marine-collected fish. All fish held at $18^{\circ} \mathrm{C}$ died within 4 weeks unless they experienced minimal handling. Gene expression correlated with infections in river-collected fish, while marine-collected fish were more stressor-responsive. Cumulative stressors were detrimental regardless of infections or collection location, likely due to extreme physiological disturbance. Because riverderived infections correlated with single stressor responses, river entry likely decreases stressor resilience of adult salmon by altering both physiological status and pathogen burdens, which redirect host responses toward disease resistance.
\end{abstract}

\section{Hosted file}

Teffer et al. Mol Ecol_Submission.pdf available at https://authorea.com/users/413609/ articles/521880-host-pathogen-environment-interactions-determine-survival-outcomes-ofadult-sockeye-salmon-oncorhynchus-nerka-released-from-fisheries 